TECHNICAL TRANSACTIONS 4/2017

CZASOPISMO TECHNICZNE 4/2017

CIVIL ENGINEERING

DOI: $10.4467 / 2353737 X C T .17 .052 .6363$

\author{
Roman Milwicz (roman.milwicz@put.poznan.pl) \\ Jerzy Pasławski \\ Institute of Structural Engineering, Faculty of Civil and Environmental Engineering, \\ Poznan University of Technology
}

\title{
MULTIPHASE CONSTRUCTION IN SINGLE FAMILY HOUSING. CASE STUDY
}

ETAPOWE BUDOWNICTWO JEDNORODZINNE. ANALIZA PRZYPADKU

\begin{abstract}
The dynamic development in the construction industry allows and at the same time forces us to design buildings with the ability to adapt to changing needs. The article discusses the formal aspects and the method of financing a single family house constructed in stages, depending on changing needs. A comparison of costs for a building constructed in stages and traditional building in the Polish realities for different scenarios of changing needs. The paper also presents the literature investigating the issue of the possibility of adapting buildings to changing needs. The basic problem is the risk of a financial trap involving the construction of a large house once and the financial problems resulting from: limitation of user numbers, limitation of financial resources, rising energy prices, high probability of selling a large house at a loss.
\end{abstract}

Keywords: Flexible construction, multiphase construction, sustainable construction

\section{Streszczenie}

Dynamiczny rozwój w branży budowlanej pozwala i równocześnie zmusza do projektowania budynków z możliwością adaptacji do zmiennych potrzeb. Artykuł traktuje o możliwościach formalno-prawnych oraz sposobie finansowania domu jednorodzinnego wznoszonego etapowo w zależności od zmieniających się potrzeb. Dokonano porównania kosztów dla budynku wznoszonego etapowo oraz budynku tradycyjnego w polskich realiach dla różnych scenariuszy zmieniających się potrzeb. Przedstawiono również literaturę zajmującą się zagadnieniem możliwości adaptacji budynków do zmieniających się potrzeb. Problem podstawowy to ryzyko pulapki finansowej polegającej na budowie jednorazowo dużego domu i problemach finansowych wynikających z: ograniczenia liczby użytkowników, ograniczenia zasobów finansowych, wzrostu cen energii, duże prawdopodobieństwo sprzedaży dużego domu ze stratą.

Słowa kluczowe: elastyczność w budownictwie, budownictwo etapowe, zrównoważone budownictwo 


\section{Introduction}

In suburban and non-urban areas single-family housing is the most common way to solve the housing problem. Dynamic technology development in the construction industry makes it more efficient but also more difficult to predict. To make it possible to implement new solutions in existing buildings, the need arises to design buildings to incorporate possible changes - the ability called flexibility. This paper aims to illustrate the comparative analysis of the traditional detached house with the house constructed in stages in the case of an increase of demand for additional useful space. Phasing the construction process of a singlefamily house is a common phenomenon in the Polish reality, but it is not a process planned at the design stage and thus is characterized by large inconvenience for users - mainly by redundancy of space. Examination of the possibility of legal aspects will be an introduction to comparative analysis.

\section{Legal aspects}

Before the beginning of construction, the designer analyses user needs and opportunities associated with the investment. In the case of a detached house choice, one should take into account the occurrence of a variety of life situations. In regular houses there is an additional space for future use (redundant space). These solutions result in an increase in planned investment, which creates higher investment costs (CAPEX). Such a solution creates a so-called "financial trap". In the case of flexible solutions, the house is planned in such a way that its expansion in the case of increasing needs for additional space is simple and waste of space is minimized. There is no need to build a big house, but smaller with the option for future expansion. If the object is to be located in the areas covered by the Local Land Development Plan the possibility of a future expansion in the context of the regulations on the width of the facade or building area should be checked. In other cases application for a development decision by presenting the final appearance of the object is needed. This solution will help to avoid problems at the stage of expansion.

\section{A construction permit}

The application process for a regular construction permit is well known and associated with the submission of the application with complete project documentation according to the building [1]. The government has 60 days to issue the construction permit or submit comments. For a house constructed in stages, the process has to be divided into steps. The first looks regular and contains the first plan of the building. The next steps involve the creation of new projects for refurbishment of the house and applying for permission to expand. 


\section{Financial aspect}

Many houses are financed by banking institutions in the form of mortgage loans. On the basis of cost estimates of the planned house, the expert's opinion and investor's income, bank determines the credit terms. From 2017, on the basis of Recommendation $S$ [2] the investor is required to have financial contribution of $20 \%$ of the planned investment costs. Multi-phasing residential investment reduces the cost of construction and thus the amount of financial contribution, as well as the reduction of the mortgage costs or shortening of the loan. The next phases of construction, depending on the financial situation, can be financed with cash or by means of a mortgage in the same or another bank.

\section{Flexibility in buildings - literature review}

Adaptability to changing needs has a diverse definition in the literature, e.g. the ability to adapt. The ability to change volume, function or performance [3], ease of response to the changed conditions [4], presence of less common but more dramatic changes [5]. On the other hand, another group of researchers claim that adaptability of buildings means to remain in readiness for change in order to change or reduce the mismatch [6]. Flexibility in buildings has already been examined [7]. In this case, however, the flexibility related to the possibility of adapting house of a defined area to different needs changes over time, e.g. a varying number of users, and the possibility of adaptation by means of changing technology. The analyses are based on existing buildings undergoing adaptations. Among them are British terraced houses, four-storey blocks in Sweden, and office buildings with open space designed for selfdevelopment. In another place the need is described to design facilities to enable adaptation: "If the building does not support (technologically and technically) change and reuse you have only the illusion of sustainable construction" [8]. The work includes an extensive analysis of the literature and tries to create a holistic definition of adaptability. Interesting in terms of flexibility is also developing, showing an overview of the literature and trying to answer the question of how to design once, but for a long time [9] considerations of the economic aspects of the adaptation of the buildings can be found in the doctoral dissertation of Manewa [10]. According to Schmidt et al. [11] the ability to adapt can be divided into several categories:

- (scalability) - possibility of the volume change,

- (flexibility) - the ability to modify the space for a variety of purposes,

- (refitability) - the ability to change or renew components,

- (movability) - to change the configuration of components or movement.

There are also companies involved in buildings that allow for great flexibility in the context of increasing the volume of the building as well as its mobility. They offer modular homes allowing them to be transported and the interior to be adapted to different needs $[12,13]$. The technology is based on wooden frame or steel and the object itself is divided into modules the size of the containers allowing transport. 


\section{Case study}

The analysis proposes a hypothetical situation for a childless couple willing to build a detached house. They have limited financial resources, and therefore the construction will be financed from the assets obtained from a bank by means of a mortgage, the minimum contribution is at least $20 \%$ of the investment. The couple do not have any definite plans as to the size of the family, therefore the estimated development of the family is based on the statistics from the Central Statistical Office [14] which is presented below in Fig. 1.

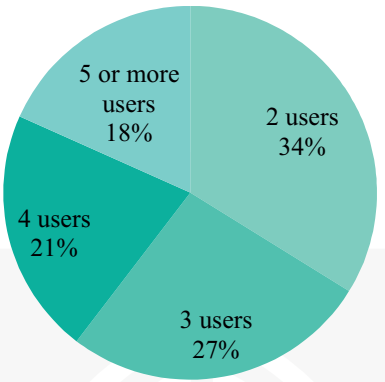

Fig. 1. The size of households with the probability of their occurrence [14]

On the basis of statistical analysis 4 scenarios are proposed: traditional (Scenario D) and flexible with 3 options and sub options (A, BI, BII, CI, CII) enabling adaptation to changing needs over time. For a given scenario, the number of instalments and credit costs have been obtained on the basis of consultation with an independent credit counsellor (interest rate of 3.4-3.6\% depending on the length and size of the loan repayment). Only loans in the Polish currency were taken into account and the amount of net salary for a household of 5000 net (average net salary in the third quarter of 2016 amounts to 3024 PLN net [15], due to the young age of the couple and small experience factor 0.8 of the average wage was used).

Table 1. Estimation of input parameters for the analysed scenarios

\begin{tabular}{|c|c|c|c|c|c|c|c|}
\hline \multicolumn{2}{|c|}{} & A & BI & BII & CI & CII & D \\
\cline { 2 - 7 } Initial Area $\left[\mathrm{m}^{2}\right]$ & 67 & 67 & 67 & 67 & 67 & 140 \\
\hline \multirow{2}{*}{$\begin{array}{c}\text { First } \\
\text { expansion }\end{array}$} & $\begin{array}{c}\text { Time from } \\
\text { the initial } \\
\text { construction }\end{array}$ & - & 5 years & 10 years & 5 years & 5 years & - \\
\cline { 2 - 8 } & size $\left[\mathrm{m}^{2}\right]$ & - & 30 & 30 & 30 & 30 & - \\
\hline \multirow{2}{*}{$\begin{array}{c}\text { Second } \\
\text { expansion }\end{array}$} & $\begin{array}{c}\text { Time from } \\
\text { the first } \\
\text { construction }\end{array}$ & - & - & - & 10 years & 15 years & - \\
\cline { 2 - 8 } & size $\left[\mathrm{m}^{2}\right]$ & - & - & - & 34 & 34 & - \\
\hline \multicolumn{2}{|c|}{ Initial capital [PLN] } & 49000 & 49000 & 49000 & 49000 & 49000 & 90 \\
\hline \multicolumn{2}{|c|}{ Instalment $[$ PLN] } & 2115 & $2115 / 1970$ & $2115 / 1740$ & $2115 / 2000$ & $2115 / 1980$ & 2050 \\
\hline
\end{tabular}




\begin{tabular}{|c|c|c|c|c|c|c|}
\hline Loan repayment period & 9 years & 14 years & 14 years & 19 years & 19 years & $\begin{array}{c}20 \\
\text { years }\end{array}$ \\
\hline $\mathrm{m}^{2} \operatorname{cost}\left[\mathrm{PLN} / \mathrm{m}^{2}\right]$ & \multicolumn{6}{|c|}{3200} \\
\hline Energy demand & \multicolumn{6}{|c|}{$120 \mathrm{kWh} / \mathrm{m}^{2}$ year } \\
\hline Unit price of energy & \multicolumn{6}{|c|}{$0.25 \mathrm{PLN} / \mathrm{kWh}$} \\
\hline
\end{tabular}

Based on the input data, a comparison of costs in the period of 20 years from the start of the investment was conducted. This period was adopted because of the payoff time of the investment and the loan repayment; additionally, the existing building is unlikely to need expansion. Option A is characterised by constant useful area at a level of $69 \mathrm{~m}^{2}$. For the other options useful area changes with time option B - $97 \mathrm{~m}^{2}$ while for option C and D - $140 \mathrm{~m}^{2}$. It can be seen that with a conventional approach, rising total costs considerably in selected categories in comparison to a flexible solution that has the advantages of reduced initial user requirements, as illustrated in Fig. 2.

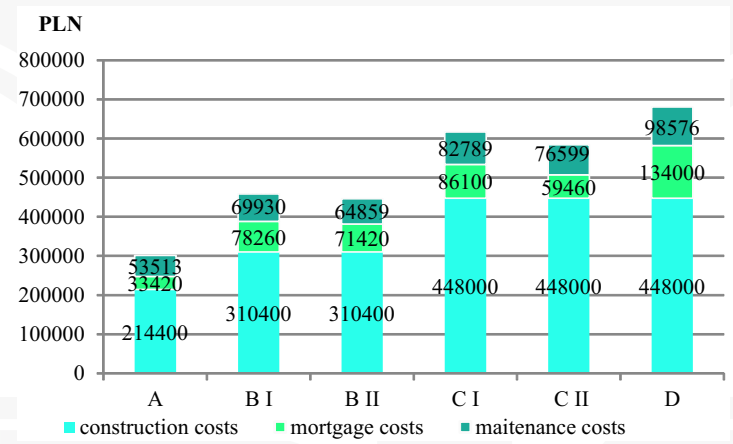

Fig. 2. Total cost (TOTEX) estimation for different options (20 year time horizon)

Differences arising from the implementation of the various options reach more than 300000 PLN for option A and D. In the case of obtaining the same usable space after the longest 15 years difference between options $\mathrm{B}$ and $\mathrm{D}$ is mainly visible in the cost of credit. If we estimate a direct relationship between the demand for usable area with the number of family members Fig. 1 the result will be relationship presented in Tab. 2 .

Table 2. Options and the ability to provide a rational surface

\begin{tabular}{|c|c|c|c|c|}
\hline & Area & No. bedroom & No. users & Occurrence \\
\hline I expansion & 30 & $1-2$ & - & - \\
\hline II expansion & 34 & $1-2$ & - & - \\
\hline A & 67 & 1 & 2 & Medium $^{*}$ \\
\hline BI/BII & 97 & $2-3$ & $3-4$ & High $^{*}$ \\
\hline CI/CII & 141 & $4-5$ & $5-6$ & Low $^{*}$ \\
\hline D & 140 & $4-5$ & $5-6$ & Low $^{*}$ \\
\hline
\end{tabular}

${ }^{*}$ values were estimated on the basis of the data presented in Fig. 1. 
Total costs associated with the mortgage and maintenance costs can also be analysed on the graph as a function of issued funds over time (Fig. 3). The visible difference can be seen at the very beginning of the investment (CAPEX) of a lower contribution from the investor and thus provide conditions for better housing affordability, which allows the investment at the lower limit of the budget. The options A and B also show significantly shorter time to repay the mortgage than in the case of $\mathrm{C}$ and $\mathrm{D}$. With option $\mathrm{C}$, we have to deal with doubleincreasing obligations to the bank.

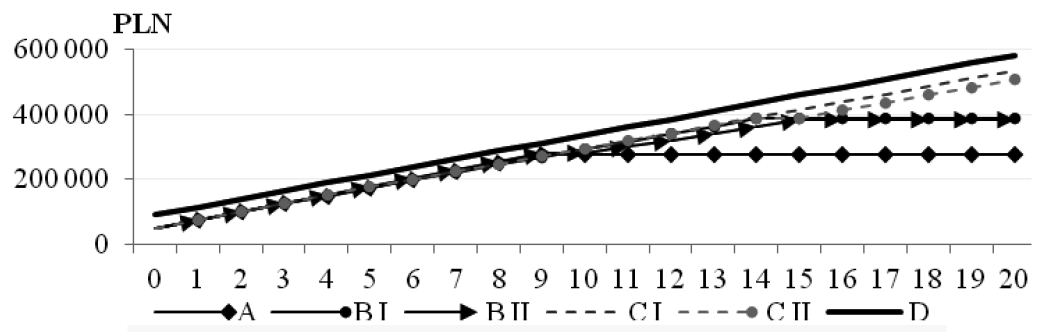

Fig. 3. The financial burden associated with the repayment of the mortgage

Flexibility application in the form of phasing construction should also bring financial benefits associated with the expenditure to cover the energy for heating purposes. The biggest differences are evident, of course, in the case of differences in the area of house after 20 years. However, even when reaching the same surface Options $C$ and $D$ investment flexibility proves to generate approximately 20000 PLN savings compared to a traditional solution.

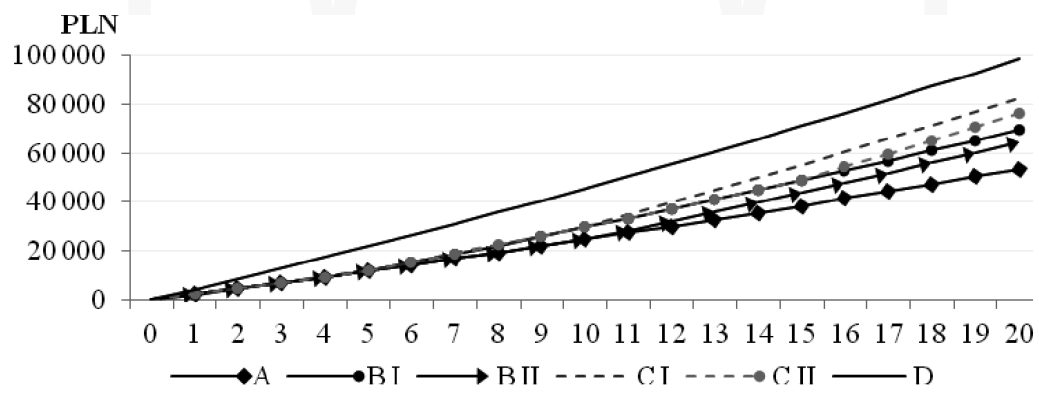

Fig. 4. Heating costs over 20 years for different options - annual price increase of $1.5 \%$

\section{Conclusions}

After the literature review, it was found that the subject discussed is widely described in the scientific community. The main conclusions are:

1. Phasing of construction is one of the flexible responses to changing conditions at the time of need.

2. Based on the analysis of Construction Law the possibility of legal application flexibility is stated in the form of staging construction. But this should be based on an individual project customized to the needs of a particular investor. 
3. Flexibility applied in this form can help to increase housing affordability (lower financial threshold of accession to the investment), by reducing their own contribution, and reduces the costs associated with mortgage, in addition to lowering energy demand;

4. Thanks to the phasing of investments, occurrence of the reduction in the risks associated with it and the lack of involvement of significant financial resources in the absence of an increase in demand for usable area and less financial obligation.

Only in a small number of cases of vague plans is there a need to invest in a house with an area of $140 \mathrm{~m}^{2}$ (Tab. 2).

The authors analysed the legal aspects and plan a further in-depth study of flexibility in residential construction from the point of view of sustainable construction based on the analysis of the life cycle costs of a building.

The publication was created with the participation of the statutory activities of the Institute of Structural Engineering Poznan University of Technology.

\section{References}

[1] Croxton R., Disassembly and Deconstruction, Architectural Record, 2003.

[2] Prawo Budowlane art. 32 ustawy z 7 lipca 1994 r. - Prawo budowlane (Dz.U. z 2006 r. $\mathrm{Nr} 156$, poz. 1118 z późn. zm.).

[3] Rekomendacja s, www.knf.gov.pl/Images/rekomendacja_s_tcm75-8566.pdf.

[4] Douglas J., Building adaptation, 2nd ed. Great Britain, Elsevier Ltd. 2006 (access: 2.12.2016).

[5] Kronenburg R., Flexibile Architecture that responds to change, Laurence King Publishers, London 2007.

[6] Leaman A., Bordass B., Flexibility and Adaptability. In designing better buildings, Macmillan S., Spon Press, 2004, 145-156.

[7] Friedman A., The adaptable house: Designing homes for change, McGraw-Hill, New York 2002.

[8] Schneider T., Till J., Flexible housing, Architectural Press, 2007.

[9] Croxton, Disassembly and Deconstruction, Architectural Record, 2003.

[10] Schneider T., Till J., Flexible Housing: The Means to the End, ARQ: Architectural Research Quarterly, 9(3/4), 2005, 287-296.

[11] Manewa R. Economic Considerations for Adaptability in Buildings PhD Thesis, https:// dspace.lboro.ac.uk/2134/9457, Loughborough 2012 (access: 8.12.2016).

[12] Schmidt R., Eguchi T., Austin S., Gibb A., What is the meaning of adaptability in the building industry, http://adaptablefutures.com/wp-content/uploads/2011/11/Schmidt-et-al.-2010b. pdf (access: 20.12.2016).

[13] Danish housing company, www.addaroom.com (access: 20.12.2016).

[14] Flexible modular housing, www.flexihus.com (access: 20.12.2016).

[15] main statistics office, www.stat.gov.pl/download/gfx/portalinformacyjny/pl/defaul taktualnosci /5670/5/1/1/1_gospodarstwa_domowe_i_rodziny_nsp2011.pdf (access: 14.12.2016).

[16] Wages calculator, www.wynagrodzenia.pl/gus (access: 10.12.2016). 


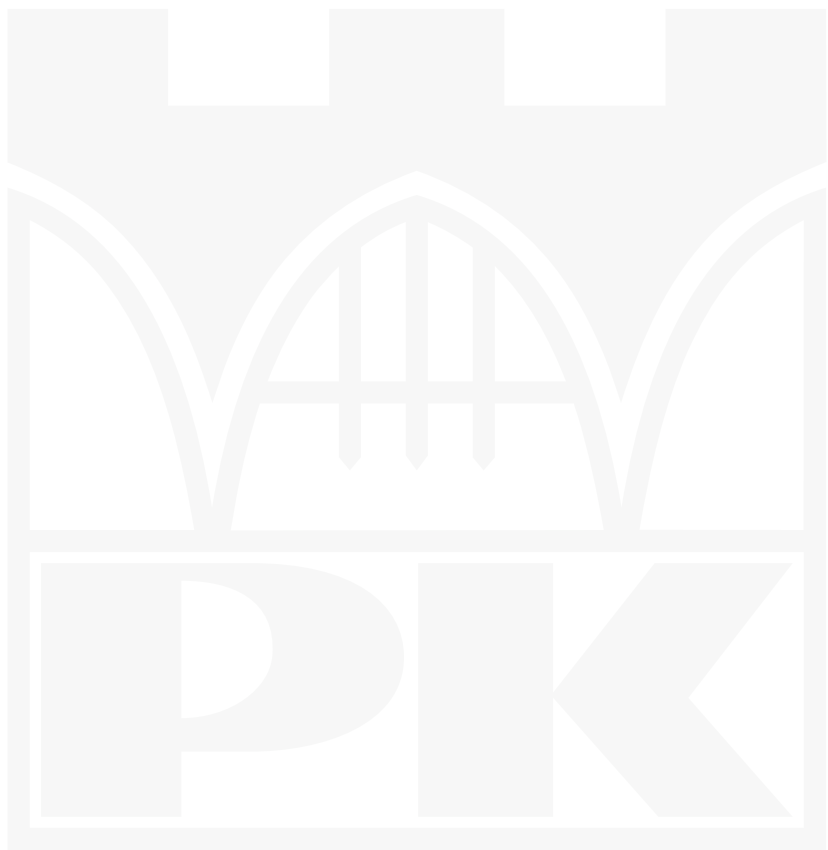

